\title{
Budaya Kerja Aparatur Sipil Negara pada Kantor Camat Idi Tunong Kabupaten Aceh Timur
}

\author{
Work Culture of the State Civil Apparatus at the Idi Tunong \\ Subdistrict Office of East Aceh Regency \\ Cut Sri Maulina*, Humaizi \& Nurman Achmad
}

Magister Studi Pembangunan, Program Pascasarjana, Universitas Sumatera Utara, Indonesia.

Diterima: 27 Februari 2020; Disetujui: 09 April 2020; Diterbitkan: 01 Juli 2020

\begin{abstract}
Abstrak
Tujuan penelitian ini untuk melihat budaya kerja dan faktor-faktor yang mempengaruh budaya kerja pegawai di Kantor Camat Idi Tunong. Metode penelitian deskriptif dengan pendekatan kualitatif. Teknik pengumpulan data yaitu melalui observasi, wawancara dan dokumentasi. Informan penelitian ini adalah informan kunci yaitu Camat Idi Tunong dan Kasubbag Umum dan Kepegawaian, informan utama yaitu pegawai Kantor Camat Idi Tunong dan informan tambahan yaitu masyarakat yang mendapatkan pelayanan Kantor Camat Idi Tunong. Teknik analisis data yaitu reduksi data, penyajian data, dan penarikan kesimpulan. Hasil penelitian ini adalah budaya kerja Kantor Camat Idi Tunong dalam hal keterbukaan informasi, saling menghargai, kerjasama antar pegawai telah terlaksana dengan baik hanya pada disiplin kerja pegawai masih kurang maksimal dan perlu untuk ditingkatkan. Sedangkan, untuk faktor-faktor yang mempengaruhi budaya kerja Kantor Camat Idi Tunong seperti budaya organisasi, budaya luar, proses pembelajaran dan motivasi telah memberikan pengaruh terhadap budaya kerja Kantor Camat Idi Tunong, sedangkan untuk perilaku pemimpin, seleksi pegawai, kejelasan misi, kepastian misi, keteladanan pemimpin masih belum memberikan pengaruh budaya kerja yang ada di Kantor Camat Idi Tunong.

Kata Kunci: Budaya Kerja, Aparatur Sipil Negara
\end{abstract}

\begin{abstract}
The purpose of this study was to look at work culture and the factors that influence the work culture of employees in the Idi Tunong Subdistrict Office. Descriptive research method with a qualitative approach. Data collection techniques are through observation, interviews and documentation. The informants of this research are the key informants namely the Idi Tunong Sub-District Head and the Public and Personnel Kasubbag, the main informants are employees of the Idi Tunong Sub-District Office employee and additional informants are the people who get the services of the Idi Tunong Sub-District Office. Data analysis techniques are data reduction, data presentation, and drawing conclusions. The results of this study are the work culture of the Idi Tunong Sub-District Office in terms of information disclosure, mutual respect, cooperation between employees has been carried out well only in employee work discipline is still not optimal and needs to be improved. Meanwhile, for factors that influence the work culture of the Idi Tunong Subdistrict Office such as organizational culture, external culture, learning process and motivation have an influence on the work culture of the Idi Tunong Subdistrict Office, while for leader behavior, employee selection, mission clarity, mission certainty, exemplary leaders still have not influenced the work culture in the Idi Tunong Sub-District Office.

Keywords: Work Culture, State Civil Apparatus.
\end{abstract}

How to Cite: Maulina, C.S Humaizi \& Achmad, N (2020). Budaya Kerja Aparatur Sipil Negara pada Kantor Camat Idi Tunong Kabupaten Aceh Timur. PERSPEKTIF, 9 (2): 270-284

*Corresponding author: ISSN 2085-0328 (Print)

E-mail: maulinacutsri@gmail.com ISSN 2541-5913 (online) 


\section{PENDAHULUAN}

Berbicara mengenai organisasi pemerintahan tentu hal pertama yang akan terpikir oleh kita adalah mengenai budaya yang ada di dalamnya, baik itu dari cara bekerja, hubungan sesama pegawai atau dengan pemimpinnya, keramah tamahan pegawai, keterbukaan dengan hal-hal baru dan sebagainya. Budaya di dalam instansi merupakan cerminan nilai-nilai, norma-norma, perilaku dan sikap dari para anggotanya yang kemudian menjadi sebuah pondasi kuat yang menggambarkan bagaimana para pegawai dalam setiap aktivitas sehari-hari melaksanakan kewajibannya, kegiatan yang dilaksanakan oleh para pegawai menjadi budaya kerja. Sehingga dapat dikatakan bahwa budaya kerja merupakan suatu pemahaman, sikap, perilaku, pola pikir, adat istiadat yang dianut dan diterapkan oleh para pegawainya dalam melaksanakan pekerjaannya di dalam organisasi tempat ia bekerja.

Budaya kerja merupakan nilai-nilai dalam sebuah organisasi dimana nilai itu akan menentukan kualitas pekerjaan para pegawainya, apabila para pegawai dapat bekerja dengan menerapkan budaya kerja produktif atau budaya kerja positif maka dapat dipastikan para pegawai dapat meningkatkan kemampuan kualitas kerjanya dan pelayanan yang diberikan baik itu kepada instansi tempatnya bekerja atau juga kepada masyarakat. Tetapi, selain budaya kerja positif terdapat juga budaya kerja negatif yang dilaksanakan oleh para pegawai instansi pemerintah maupun swasta. Salah satu contoh budaya kerja negatif di instansi pemerintah yaitu masih banyaknya pegawai yang bermasalah dalam disiplin terutama dalam hal kehadiran ataupun dalam penyelesaian tugas (Mujiburrahman, 2011),.

Pegawai pemerintah atau Aparatur Sipil Negara (ASN) merupakan roda penggerak birokrasi dan juga sebagai abdi negara dan abdi masyarakat harus dapat membentuk budaya kerja positif seperti melaksanakan tugasnya secara efektif dan efisien sehingga citra para Aparatur Sipil Negara (ASN) yang selama ini dianggap negatif di mata masyarakat karena sering bermasalah dengan kehadiran dan semangat kerja yang rendah sehingga harus diperbaiki. Budaya kerja Aparatur Sipil Negara (ASN) yang rendah diakibatkan dari kurangnya para pegawai dalam memaknai tugasnya sebagai abdi negara dan abdi masyarakat hanya sebagai suatu pekerjaan rutin sehingga tidak menjiwai bahwa sebagai Aparatur Sipil Negara (ASN) mereka adalah orang yang harusnya dapat memberikan pelayanan terbaik kepada masyarakat yang telah mempercayai mereka sebagai pengayom masyarakat.

Permasalahan yang sering terjadi dalam instansi pemerintah mengenai budaya kerja Aparatur Sipil Negara (ASN) yaitu penilaian negatif dari masyarakat mengenai kualitas pelayanan yang diberikan oleh para pegawai; kurangnya tingkat disiplin pegawai sehingga pelayanan yang diberikan kepada masyarakat menjadi berkurang dan tidak memuaskan; nilai-nilai budaya yang tidak dilaksanakan oleh para pegawai menambah citra negatif di mata masyarakat (Hatelea, 2014). Sama halnya seperti yang dijelaskan oleh The Liang Gee (Moenir, 1983) yang menyatakan bahwa : "Dalam praktek, Pegawai Negeri Sipil Di Indonesia pada umumnya masih banyak kekurangan yaitu kurang mematuhi kedisiplinan pegawai, sehingga dapat menghambat kelancaran pemerintahan dan pembangunan nasional, antara lain adalah masih adanya jiwa kepegawaian dalam berfikir mengikuti kebiasaan, bukan terletak pada kesatuan yang harmonis melainkan kesatuan pada bagian-bagian tersendiri, mempunyai bentuk dan corak yang berbeda serta kurang menghargai ketepatan waktu".

Pernyataan The Liang Gee di atas telah dirasakan oleh masyarakat yang kecewa terhadap pelayanan Aparatur Sipil Negara (ASN). Budaya kerja yang negatif tersebut juga dapat terlihat dari pernyataan Badan Kepegawaian Negara Republik Indonesia (BKN RI) pada Tahun 2017 telah mencatat bahwa sebanyak 1.759 (Seribu tujuhratus limapuluh sembilan) Aparatur Sipil Negara (ASN) telah dijatuhi hukuman disiplin, mulai dari hukuman dari tingkat berat, sedang hingga ringan dengan rincian bahwa hukuman yang paling banyak diberikan atas pelanggaran terhadap ketentuan jam kerja yaitu sekitar 570 (Limaratus tujuhpuluh) kasus sedangkan untuk pelanggaran lain karena kasus tidak menjunjung tinggi kehormatan negara, pemerintah dan martabat Aparatur Sipil Negara (ASN), tidak melaksanakan tugas kedinasan yang dipercayakan serta 
menyalahgunakan

wewenang

(Tribunnews.com).

Penilaian negatif dari masyarakat mengenai budaya kerja pegawai perlu dilakukan pengkajian kembali dengan upaya reformasi birokrasi secara keseluruhan, sehingga budaya kerja Aparatur Sipil Negara (ASN) menjadi lebih efisien dan efektif dan tentu saja dapat merubah pandangan negatif dari masyarakat selama ini. Cara pandang Aparatur Sipil Negara (ASN) terhadap budaya kerja akan sangat berpengaruh terhadap sikap dan perilaku mereka yang kemudian akan dicerminkan dari motivasi Aparatur Sipil Negara (ASN) dalam bekerja, dedikasi, kreativitas dalam menjalankan tugasnya, serta kemampuan dan komitmen yang tinggi tentu akan terlihat dalam setiap kegiatan yang dilakukan setiap harinya sehingga pelayanan yang akan diberikan kepada masyarakat akan memuaskan.

Mengenai budaya kerja seperti nilai-nilai didalam instansi merupakan cerminan dari para pegawai, hal tersebut juga terdapat di Kantor Camat Idi Tunong. Kantor Camat Idi Tunong sebagai instansi pemerintah yang berlokasi di Kecamatan Idi Tunong tentu saja memiliki budaya kerja yang dilaksanakan oleh para Aparatur Sipil Negara (ASN) yang bertugas di kantor tersebut. Budaya kerja di Kantor Idi Tunong lebih cenderung kepada budaya kerja yang negatif, alasan budaya kerja negatif yaitu berdasarkan pengamatan Peneliti yang melihat banyaknya pelanggaran yang dilakukan Aparatur Sipil Negara (ASN) di Kantor Camat Idi Tunong terutama dalam hal disiplin kerja, masih kentalnya budaya setempat, pengaruh partai politik, serta adanya diskriminasi pegawai.

Budaya kerja negatif di Kantor Camat Idi Tunong terutama dalam hal disiplin kerja yaitu banyaknya Aparatur Sipil Negara yang terlambat masuk kerja. Keterlambatan tersebut dengan berbagai alasan seperti jarak rumah dan lokasi kantor sangat jauh, infrastruktur jalan yang buruk, pekerjaan rumah tangga yang terlebih dahulu diselesaikan, jumlah gaji yang dirasakan tidak sesuai dengan biaya yang harus dikeluarkan oleh pegawai sehingga terjadinya shif kerja diantara pegawai, masih menggunakan daftar kehadiran manual juga menjadi penyebab pelanggaran disiplin. Kentalnya budaya setempat seperti pola pikir, cara berbicara, sikap dan perilaku yang masih kental dengan kearifan lokal masih memberikan kontribusi terhadap budaya kerja di Kantor Camat Idi Tunong, seperti para pegawai yang kurang menghargai pemimpin atau camat yang bukan berasal dari daerahnya atau putra daerah. Terkadang pegawai tidak begitu mengindahkan perintah yang diberikan Camat, mereka lebih mendengarkan para tetua atau tokoh adat setempat.

Perilaku pegawai tersebut adalah salah satu budaya negatif di Kantor Camat Idi Tunong lainnya yang tidak menghargai Camat yang bukan putra asli daerah. Tidak menghargai disini seperti pegawai sering tidak mengindahkan perintah camat, mereka menganggap bahwa yang sepatutnya menjadi camat adalah putra asli Idi Tunong. Pegawai lebih menghargai dan mendengarkan kepala desa atau Geuchik dari pada camat. Untuk mengatasi hak tersebut maka Camat Idi Tunong selalu mengajak pegawai, geuchik dan tokoh adat setempat untuk dapat berkumpul bersama di sela-sela waktu luang dengan tujuan untuk mempererat hubungan silaturahmi dengan geuchik dan tokoh adat setempat dan juga untuk mendapatkan kepercayaan dari para pegawai karena telah mendapat dukungan geuchik dan tokoh adat di sekitar Kantor Camat Idi Tunong.

Selain itu, Pada Kantor Camat Idi Tunong seringnya terjadi hal-hal yang diluar logika atau seperti contoh camat yang bertugas di Kantor Camat Idi Tunong dalam menjalankan tugas hanya akan bertahan dalam waktu singkat. Hal tersebut Peneliti amati bahwa Camat yang bertugas sering sekali sakit padahal awal penempatan Camat tersebut terlihat sehat, pergantian Camat yang bertugas di Kantor Camat Idi Tunong juga disebabkan seringnya terjadi mutasi dengan alasan yang tidak jelas. Pegantian Camat di Kantor Camat Idi Tunong dapat dilihat pada Tabel 1.1.

Perilaku dari pegawai tersebut menjadi nilai-nilai yang tercermin di dalam Kantor Camat Idi Tunong apabila berlangsung dalam waktu lama maka tertanam kuat sehingga menjadi kebiasaan yang pada akhirnya menciptakan sebuah budaya kerja yang akan sulit untuk dirubah. Kebiasaan perilaku Pegawai Negeri di Kantor Camat Idi Tunong menjadi alasan Peneliti untuk melakukan penelitian mengenai budaya kerja pegawai Kantor Camat Idi Tunong karena Peneliti 
merupakan bagian dari pegawai di Kantor Camat tersebut sehingga mengetahui seluk beluk budaya kerja yang ada.

\section{METODE PENELITIAN}

Menurut Moeloeng (2003) metode penelitian deskriptif dengan pendekatan kualitatif bemaksud untuk memahami kejadian-kejadian ynag dialami oleh subjek penelitian seperti perilaku, motuvasi, tindakan dan persepsi secara holistik dengan cara deskripsi baik itu dalam bentuk kata-kata dan bahasa pada konteks tertentu dengan memanfaatkan berbagai metode ilmiah. Sedangkan Martono (2016) mengatakan bahwa metodologi penelitian deskriptif berkaitan sebuah pertanyaan tentang "apa fenomena yang akan diteliti”. Penelitian deskriptif tidak untuk menjelaskan hubungan antara gejala sosial yang satu dengan yang lain melainkan hanya untuk memberikan gambaran karakterk suatu kelompok, variabel dan gejala sosial yang terjadi di masyarakat.

Penelitian deskriptif digunakan dalam penelitian ini karena Peneliti menggambarkan dan menjelaskan keadaan yang terjadi di lapangan. Data yang telah dihasilkan masih berebentuk kata-kata atau kalimat yang kemudian dieksplorasi untuk dapat memberikan informasi bagaimana kenyataan sosial yang terjadi dilapangan dengan masalah yang diteliti. Penelitian dengan menggunakan pendekatan kualitatif digunakan untuk menggambarkan dengan jelas mengenai Budaya Kerja Aparatur Sipil Negara Pada Kantor Camat Idi Tunong Kabupaten Aceh Timur.

Lokasi penelitian ini dilakukan di Kantor Camat Idi Tunong Kabupaten Aceh Timur yang beralamat di Jalan Seuneubok, Idi Tunong, Kabupaten Aceh Timur. Kantor Camat Idi Tunong dipilih sebagai lokasi penelitian karena berdasarkan pengamatan Peneliti menunjukkan bahwa budaya kerja negatif seperti masih banyak pegawai yang tidak mematuhi peraturan terutama dalam hal masuk kerja. Ketidakdisiplinan para pegawai khususnya dalam hal masuk kerja yang dilakukan setiap hari tanpa adanya sanksi yang tegas membuat hal tersebut menjadi sebuah kebiasaan yang diangggap biasa yang pada akhirnya menjadi sebuah budaya. Keterlambatan para pegawai tentu akan memberikan dampak terhadap kinerja pegawai dan juga memberikan kesan buruk kepada masyarakat sehingga masyarakat meragukan pelayanan yang dilakukan oleh para pegawai. Selain itu, yang menjadi alasan dipilihnya Kantor Camat Idi Tunong karena Peneliti adalah salah satu pegawai yang berkerja di Kantor Camat Idi Tunong tersebut sehingga Peneliti telah mengenal baik kondisi para pegawai serta lokasi penelitian dengan baik. Oleh sebab itu, Peneliti dapat memperoleh informasi data yang berhubungan masalah penelitian secara objektif.

Subjek Penelitian menurut Idrus (2009) adalah individu, benda atau organisme yang menjadi sumber informasi yang dibutuhkan dalam pengumpulan data penelitian. Nama lain subjek penelitian adalah responden atau orang yang memberikan respon atas perlakuan yang diterimanya. Bebicara subjek penelitian pada hakikatnya kita berbicara unit analisis yaitu subjek yang menjadi pusat sasaran atau perhatian penelitian. Subjek penelitian ini yaitu semua pegawai Kantor Camat Idi Tunong yang berjumlah 40 orang.

Istilah populasi dan sampel tidak digunakan pada penelitian kualitatif seperti pada penelitian kuantitatif. Suyanto (2005) mengatakan bahwa informan penelitian meliputi: Informan kunci, yaitu orang yang mengetahui secara detail seluk beluk data dan informasi mengenai permasalahan yang diteliti. Informan kunci dalam penelitian ini adalah Camat, KASUBBAG Umum dan Kepegawaian yang memahami tentang peraturan disiplin PNS dan atasan yang mengawasi secara langsung Aparatur Sipil Negara di Kantor Camat Idi Tunong Kabupaten Aceh Timur. Informan utama, yaitu orang yang secara langsung terlibat dalam berinteraksi sosial yang diteliti. Informan utama penelitian ini adalah pegawai yang berada di Kantor Camat Idi Tunong Kabupaten Aceh Timur. Informan Tambahan yaitu Masyarakat yang mendapatkan pelayanan di Kantor Camat Idi Tunong dan Badan Kepegawaian Daerah Kabupaten Aceh Timur yang melaksanakan manajemen kepegawaiaan di Kabupaten Aceh Timur.

Menurut Suyanto (2005) terdapat tiga macam cara pengumpulan data dalam penelitian kualitatif yaitu: Wawancara mendalam dan terbuka. Melalui wawancara maka data diperoleh merupakan informasi 
langsung dari orang-orang tentang pengalaman, pendapat, perasaan dan pengetahuannya mengenai masalah yang ditetliti. Dalam penelitian ini peneliti telah terlebih dahulu mempersiapkan daftar wawancara terkait budaya kerja Aparatur Sipil Negeri di Kantor Camat Idi Tunong serta faktor yang mempengaruhi budaya kerja para pegawai. Observasi langsung. Pengumpulan data melalui observasi langsung akan mendapatkan data yang terdiri atas rinci tentang kegiatan, tindakan orang-orang, perilaku, interkasi tindakan interpersonal dan proses penataan yang merupakan bagian dari pengalaman mausia yang dapat diamati. Dalam observasi peneliti secara langsung memperhatikan bagaimana para pegawai sehari-hari dalam menerapkan disiplin kerja dengan cara memperhatikan ketepatan dalam masuk kerja, pada saat melaksanakan tugasnya selama bekerja sampai waktunya untuk pulang kerja.

Penelaahan terhadap dokumen tertulis. Penelaaan dokumen akan memberikan data berupa kutipan, cuplikan atau penggalanpenggalan dari catatan-catatan organisasi, program atau klinis; memorandummemorandum dan korespondensi, buku harian pribadi; terbitan dan laporan resmi dan jawaban tertulis yang terbuka terhadap survei dan kuesioner. Penelaahan disini penulis memperoleh data mengenai absensi pegawai dari KASUBBAG Umum Dan Kepegawaian, melalui dokumen lainya seperti Peraturan Pemerintah No. 53 Tahun 2010 tentang Peraturan Disiplin Pegawai Negeri, UndangUndang No. 5 Tahun 2014 tentang Aparatur Sipil Negara dan dokumen lainya yang berhubungan dengan peneltian.

Analisis data adalah proses kegiatan pengelolaan, interpretasi, penyajian, dan analisis data yang didapatkan dari lapangan dengan tujuan data yang disajikan memiliki makna, sehingga pembaca dapat mengetahui dan memahami hasil penelitian yang kita lakukan. Miles dan Huberman (Silalahi, 2009) mengatakan bahwa teknik analisis data pada penelitian kualitatif terdiri dari tiga alur yaitu : Reduksi data adalah kegiatan dalam proses pemilihan, pengabstrakan, pemusatan perhatian pada penyederhanaan dan transformasi data kasar yang muncul dari catatan-catatan tertulis di lapangan. Reduksi data adalah suatu bentuk analisis yang mengarahkan, menggolongkan, menajamkan, membuang yang tidak perlu, dan mengorganisasikan data sedemikian rupa sehingga mendapatkan kesimpulankesimpulan final untuk ditarik dan diverifikasi. Proses transformasi atau reduksi data berlanjut terus sesudah penelitian lapangan sampai laporan akhir tersusun lengkap.

Penyajian data dapat dikatakan sebagai sekumpulan informasi yang tersusun dan memberikan kemungkinan adanya penarikan kesimpulan serta pengambilan tindakan. Melalui data yang disajikan kita dapat melihat dan memahami peristiwa yang terjadi, apa yang harus dilakukan dan lebih jauh menganalisis ataukah mengambil tindakan berdasarkan atas pemahaman yang didapat dari penyajian-penyajian tersebut.

Tahapa penarikan kesimpulan adalah kegiatan yang dilakukan pada tahap selanjutnya setelah pengumpulan data telah dilakukan, maka peneliti mulai mencari arti dari benda-benda, pola-pola, penjelasan, mencatat keteraturan, konfigurasi-konfigurasi yang mungkin, alur sebab akibat, dan proposisi. Pada tahap penarikan kesimpulan disini Peneliti akan menarik kesimpulan secara cermat dengan melakukan tinjauan ulang informasi yang didapat melalui catatancatatan yang didapat dari lapangan sehingga dapat diuji validitasnya.

\section{HASIL DAN PEMBAHASAN \\ Budaya Dispilin Kerja Kantor Camat Idi Tunong}

Secara umum disiplin dapat dikatakan sebagai perilaku yang taat dan patuh terdap nilai-nilai yang berlaku dalam sebuah organisasi dimana para anggotanya harus mematuhinya dan merupakan tanggungjawab dari setiap anggota organisasi untuk dapat mematuhinya. Pentingnya disiplin adalah untuk dapat membuat semua tugas yang harus diselesaikan tepat waktu, meningkatkan kinerja pegawai dan menumbuhkan rasa tanggungjawab pada pegawai untuk dapat mencapai tujuan dari organisasi. Mengenai budaya kerja yang berhubungan dengan disiplin Aparatur Sipil Negara di Kantor Camat Idi Tunong, maka berikut ini adalah hasil wawancara yang dilakukan oleh Peneliti dengan Bapak Camat Idi Tunong, Bapak Bai Haqi S.Ag. 
Makna sebuah disiplin dalam budaya kerja bahwa disiplin itu merupakaan perilaku yang senantiasa berpijak kepada peraturan dan norma yang berlaku di dalam organisasi atau yang berlaku di Kantor Camat Idi Tunong. Sesuai dengan yang telah dijelasan oleh Darodjat (2015) bahwa Disiplin meliputi ketaatan terhadap peraturan perundangundangan, prosedur, waktu kerja, berinteraksi dengan mitra dan sebagainya. Penjelasan Darodjat mengenai disiplin kerja masih jauh dari yang diharapkan, berdasarkan informasi dari para informan yang Peneliti peroleh melalui wawancara bahwa kebanyakan pegawai masih kurang dalam hal disiplin kerja khususnya ketepatan dalam kehadiran. Bahkan para informan yang merupakan pegawai Kantor Camat Idi Tunong juga membenarkan bahwa masih banyak para pegawai yang masih kurang dalam hal disiplin khususnya masuk kerja.

Mengenai disiplin kerja pegawai terutama di instansi pemerintah telah menjadi penilaian negatif dari masyarakat. Ketika aturan yang berlaku para pegawai yang harusnya telah hadir pukul 08.00 WIB tapi pada kenyataannya pada pukul tersebut Kantor masih sepi akan kehadiran para pegawai. Mengenai disiplin pegawai yang menjadi budaya kerja negatif juga sesuai dengan penelitian yang dilakukan oleh Hatalea tahun 2014. Penelitian Hatelea tidak jauh berbeda dari penelitian yang Peneliti lakukan yaitu mengenai Budaya Kerja Aparatur Sipil Negara di Kelurahan Mojolangu. Penelitian Hatelea megatakan bahwa penilaian negatif dari masyarakat mengenai pelayanan publik dari pegawai masih jauh dari kata memuaskan, banyak masyarakat yang merasa kecewa terhadapat para pegawai yang kurang disiplin sehingga pelayanan yang didapat menjadi kurang maksimal, penerapan nilai-nilai budaya kerja pegawai yang kurang maksimal juga menambah buruknya citra pegawai di mata masyarakat.

Hasil penelitian Hatelea (2014) di Kelurahan Mojolangu tentang budaya kerja negatif dalam disiplin pegawai ternyata juga terjadi di Kantor Camat Idi Tunong, Kabupaten Aceh Timur. Disiplin kerja menjadi budaya negatif pegawai di instansi pemerintah. Hasil wawancara dengan para pegawai Kantor Camat Idi Tunong, seperti penjelasan Camat, Kasubbag pelaporan dan para pegawai memberikan pernyataan sama bahwa para pegawai masih banyak kurang disiplin terutama dalam ketepatan waktu kerja. Informasi dari masyarakat juga mengeluhkan bahwa disiplin pegawai yang masih kurang. Penjelasan dari para informan yang telah memberikan penjelasan mengenai nilai budaya kerja negatif dalam hal disiplin. Penjelasan Darodjat juga mengenai disiplin tidak sesuai dengan keadaan di Kantor Camat Idi Tunong, membuat Peneliti memberikan kesimpulan bahwa budaya kerja pegawai dalam hal disiplin masih kurang maksimal, sehingga Kantor Camat Idi Tunong perlu melakukan evaluasi kembali mengenai disiplin kerja.

\section{Budaya Keterbukaan Kerja Kantor Camat Idi Tunong}

Keterbukaan menjadi salah satu nilai dari sebuah budaya kerja yang ada didalam organisasi. Keterbukaan menjadi sebuah landasan yang harus dimiliki semua organisasi hal tersebut penting karena dengan adanya keterbukaan maka tujuan dari organisasi dapat tercapai. Di dalam organisasi terdapat unit-unit yang memiliki tugas dan fungsinya masing-masing dan memiliki perannya tersendiri, apabila tidak ada keterbukaan dalam menerima atau memberikan informasi kepada para pegawai atau anatar unit atau seksi maka dapat dipastikan terjadinya kekacauan akibat kesalahpahaman yang ada akhirnya tujuan tidak akan pernah tercapai, oleh sebab itu keterbukaan informasi menjadi sangat penting dan menjadi nilai dari sebuah organisasi. Keterbukaan informasi sudah dapat dijalankan dengan baik di Kantor Camat Idi Tunong, hal tersebut sesuai dengan penjelasan dari Camat Idi Tunong, Bapak Bai Haqi, S.Ag.

Keterbukaan sesuai dengan penjelasan Darodjat (2015) bahwa nilai dari sebuah organisasi yaitu terdapatnya sebuah keterbukaan informasi. Anggota organisasi harus siap dalam memberikan dan menerima informasi yang benar dari dan kepada sesama mitra kerja untuk kepentingan organisasi. Keterbukaaan informasi akan membuat para pegawai mengetahui apa yang harus menjadi kewajibannya selain itu juga apabila ada infromasi penting dan terbaru semua pegawai dapat mengetahuinya. Informasi tersebut didapat secara langsung seperi pemberitahuan langsung atau secara tidak langsung melalui 
papan pengumuman dan lain-lain. Tidak semua informasi harus diketahui pegawai karena ada informasi tertentu yang hanya boleh diketahui oleh pegawai tertentu saja.

Mengenai nilai budaya kerja organisasi tentang keterbukaan informasi juga diteliti oleh Lufni pada tahun 2013. Penelitian Lufni mengenai Budaya Kerja Aparatur Kecamatan Samboja, Kabupaten Kutai Kartenegara. Hasil penelitian Lufni menyebutkan bahwa keterbukaan informasi di Kecamatan Samboja telah berjalan dengan baik hal tersebut terlihat dari keterbukaan informasi dan kesiapan untuk memberi dan menerima telah terlaksanan diantara para pegawai Kecamatan Samboja serta keterbukaan dan kemudahan masyarakat dalam mendapatkan informasi membuat masyarakat memberikan kepercayaan kepada pegawai Kecamatan Samboja.

Penjelasan dari Darodjat yang mengatakan bahwa untuk membentuk budaya kerja maka nilai yang harus ada diantara para pegawai adalah adanya keterbukaan. Keterbukaan baik diantara mitra, dengan pemimpin akan menciptakan kepercayaan sehingga kinerja yang dihasilkan lebih produktif. Tidak hanya pada lingkungan kerja keterbukaan informasi kepada masyarakat juga akan membuat masyarakat kepada pegawai. Keterbukaan informasi di Kantor Camat Idi Tunong telah berjalan dengan baik, hal tersebut Peneliti katakan bahwa dari hasil wawancara para informan terutama pegawai Kantor Camat Idi Tunong menyebutkan bahwa informasi di Kantor Camat dapat diperoleh dengan mudah. Masyarakat yang menjadi informan juga menyebutkan bahwa ketika mereka memiliki urusan di Kantor Camat Idi Tunong, mereka dengan mudah memperolehnya baik dari pengumuman yang ada di Kantor Camat Idi Tunong ataupun langsung mendapatkan penjelasan dari para pegawai.

Sesuai dengan penjelasan dari Darodjat tersebut dan juga sesuai dengan informasi yang Peneliti dapat dari para informan yang telah memberikan penilian terhadap keterbukaan informasi di Kantor Camat Idi Tunong serta sejalan dengan penelitian yang dilakukan oleh Lufni (2013) maka Peneliti mempertegas kembali bahwa salah satu dari nilai budaya kerja di Kantor Camat Idi Tunong tentang keterbukaan informasi telah terlalaksana dengan baik diantara para pegawai dan juga masyarakat yang dilayani oleh pegawai Kantor Camat Idi Tunong.

\section{Budaya Saling Menghargai Kerja Kantor Camat Idi Tunong}

Saling menghargai satu sama lain diantara pegawai ataupun menghargai masyarakat yang datang dalam hal kepentingan tertentu di Kantor Camat Idi Tunong merupakan sebuah nilai budaya yang dapat menggambarkan perilaku budaya kerja Kantor Camat Idi Tunong. Saling menghargai merupakan nilai budaya yang nenunjukkan perilaku pegawai saat memberikan penghargaan kepada rekan kerjanya dalam tanggungjawab penyelesaian tugas. Selain itu saling menghargai juga adalah sikap perilaku yang harus ditunjukkan oleh seluruh pegawai untuk dapat menerima perbedaan diantara mereka karena perbedaan latar belakang setiap pegawai berbeda-beda, serta tidak ada anggapan bahwa dirinya lebih baik dari orang lain. Saling menghargai sangat dibutuhkan dalam menjalankan roda pemerintahan Kantor Camat Idi Tunong.

Saling menghargai merupakan sebuah perilaku yang menunjukkan penghargaan terhadap individu, tugas dan tanggung jawab orang lain sesama mitra kerja (Darodjat, 2015). Pentingnya menghargai rekan kerja akan dapat mempererat hubungan diantara sesama rekan kerja yang tentu saja akan berdampak terhadap kualitas kerja yang dihasilkan. Hal yang telah dikemukaan oleh Darodjat tersebut juga telah sesuai dengan penjelasan dari semua informan yang telah Peneliti wawancarai. Para pegawai menjelaskan bahwa saling menghargai antara rekan kerja telah terlaksana dengan baik sehingga menciptakan keserasian dan kerukunan di antara pegawai. Saling menghargai juga akan mempererat hubungan silaturahmi diantara pegawai. Budaya kerja positif akan tercipta dengan adanya saling menghargai. Pegawai Kantor Camat sebagai makhluk sosial pasti menginginkan untuk dihargai, merasa dihargai akan membuat mereka lebih nyaman dalam bekerja sehingga dapat memberikan kinerja terbaik yang dimiliki.

Saling menghargai sebagai nilai dari budaya kerja telah terlaksana di antara pegawai juga telah terlaksana di Kecamatan 
Samboja, Kabupaten Kutai Kartanegara. Hasil penelitian oleh Lufni tahun 2013 mengenai Budaya Kerja Aparatur Kecamatan Samboja, Kabupaten Kutai Kartenegara menjelaskan bahwa pegawai Kecamatan Samboja telah menunjukan saling menghargai di antara sesama pegawai, penghargaan terhadap tugas dan tanggung jawab. Berdasarkan hasil penelitian terdahulu oleh Lufni dan berdasarkan penjelasan Darodjat serta hasil wawancara dari para informan di Kantor Camat Idi Tunong, maka disini Peneliti membuat suatu kesimpulan bahwa saling menghargai di Kantor Camat Idi Tunong telah terlaksana dengan baik. Saling menghargai telah dijalankan baik itu diantara para pegawai dan juga masyarakat yang datang untuk mengurus kepentingan di Kantor Camat Idi Tunong.

\section{Budaya Kerja Sama Kerja Kantor Camat Idi Tunong}

Sebagai makhluk sosial manusia perlu melakukan interaksi dengan lingkungannya, baik sesama manusia maupun dengan makhluk lainnya. Aktivitas yang dilakukan sehari-hari selalu membutuhkan kehadiran orang lain atau bahkan harus bekerjasama untuk mendapatkan hasil yang lebih maksimal. Hal tersebut juga berlaku dalam instansi pemerintah seperti Kantor Camat Idi Tunong. Kerja sama yang dilakukan merupakan sebuah usaha diantara para pegawai baik perorangan maupun kelompok diantara kedua belah pihak sepakat untuk melakukan kerja secara bersama-sama sehingga dapat memberikan hasil yang lebih cepat dan lebih baik lagi. Nilainilai budaya kerja salah satunya adalah kerja sama yang dilakukan oleh seluruh pegawai Kantor Camat Idi Tunong, dengan adanya kerjasama dalam kesediaan para pegawai untuk memberikan dan menerima kontribusi dari dan atau kepada mitranya sebagai sesama pegawai untuk dapat mencapai target dan sasaran dari Kantor Camat Idi Tunong.

Kerjasama dalam penyelesaian sebuah tugas akan memberikan kemudahan dan menghasilkan hasil yang maksimal. Kerjasama merupakan salah satu nilai budaya kerja dalam organisasi. Kerjasama diantara pegawai akan membuat organisasi lebih mudah dalam menjacapai tujuan. Kerjasama menurupakan nilai budaya kerja seperti yang dijelaskan oleh Darodjat (2015). Darodjat mengatakan bahwa kerjasama akan membuat pegawai untuk dapat menerima dan memberikan kontibusi dari dan atau sesama mitra kerja agar target organisasi dapat terlaksana dengan baik. Disisi lain, pegawai sebagai makhluk sosial membutuhkan orang lain dalam menjelankan aktuvitasnya atau pun dalam memenuhi kebutuhannya. Hal yang sama juga pada penyelesaian tugas dalam lingkungan kerja, pada saat tertentu ada tugas yang di selesaikan sendiri dan disisi lain hanya bisa diselesaikan dengan adanya kerjasama diantara pegawai.

Kerjasama akan menciptakan budaya kerja juga dijelaskan oleh Lufni (2013) melalui penelitiannya mengenai Budaya Kerja Aparatur Kecamatan Semboja, Kabupaten Kutai Kartanegara. Hasil penelitian Lufni mengatakan bahwa kerjasama para pegawai di Kecamatan Semboja telah terlaksana dengan cukup baik hal tersebut terlihat dari kerjasama diantara pegawai akan memberikan saling kepercayaan dan rasa saling mendukung untuk dapat mencapai tujuan organisasi. Saling percaya, saling mendukung diantara pegawai akan menciptakan nilai sehingga budaya kerja positif. Kerjasama diantara pegawai juga telah terlaksana di Kantor Camat Idi Tunong. Kabupaten Aceh Timur. Kerjasama tersebut disimpulkan dari jawaban para informan kepada Peneliti mengenai kerjasama diantara pegawai telah terlaksana dengan baik. Para informan telah menjelaskan bahwa selesainya tugas tidak terlepas dari kerjasama diantara rekan kerja.

Seperti yang telah dijelaskan bahwa kerjasama diantara pegawai pada hakikatnya dapat membentuk kepercayaan diantara para pegawai Kantor Camat Idi Tunong, semakin tinggi rasa percaya mereka terhadap rekan kerjanya maka dapat dipastikan kerjasama yang dilakukan juga akan semakin lebih baik dan juga akan menghasilkan sebuah sinergi yang positif melalui koordinasi yang baik. Kerjasama akan membuat pegawai bersedia untuk memberikan dan menerima kontribusi dari dan atau kepada rekan kerjanya dalam mencapai sasaran dan target dari organisasi mereka bekerja. Oleh karena, melihat dari penjelasan Darodjat, hasil penelitian Lufni dan hasil wawancara para informan membuat Peneliti dapat menyimpulkan bahwa kerjasama diatar pegawai merupakan cara paling ampuh ataupun paling efektif untuk menyatukan seluruh pegawai yang ada di 
Kantor Camat Idi Tunong. Kerjasama merupakan nilai yang akan menciptakan budaya kerja positif. Sehingga kerjasama antar pegawai di Kantor Camat Idi Tunong telah berjalan dengan baik.

\section{Faktor-Faktor yang Mempengaruhi Budaya Kerja Kantor Camat Idi Tunong}

Budaya kerja merupakan turunan dari budaya organisasi, dimana budaya organisasi tersebut adalah sitem nilai yang terkandung didalam instansi tersebut dalam menjalankan fungsinya sebagai sebuah instansi pemerintah. Hal paling penting dalam memberikan pengaruh budaya kerja adalah kepercayaan dan juga sikap pegawai yang ada didalamnya apakah akan menghasilkan budaya positif atau negatif. Budaya kerja yang positif tentu akan meningkatkan produktifitas kerja para pegawainya sedangkan budaya kerja negatif akan memberikan pengaruh yang sebaliknya berupa hambatan efektivitas bagi seluruh pegawai. Untuk dapat menciptakan budaya kerja itu sendiri tentu dipengaruhi oleh faktorfaktor tertentu seperti yang telah dijelaskan pada kajian pustaka bahwa budaya kerja dapat dipengaruhi oleh faktor kepemimpinan, seleksi para pegawai, budaya organisasi itu sendiri, budaya dari luar, kejelasan visi dan misi perusahaan, kepastian visi perusahaan, keteladanan pemimpin, proses pembelajaran pegawai dan motivasi yang didapatkan oleh pegawai.

Untuk lebih jelasnya faktor yang mempengaruhi budaya kerja yang ada di Kantor Camat Idi Tunong, berikut ini adalah hasil wawancara dengan para informan, baik itu Camat dan pegawai Kantor Camat Idi Tunong serta masyarakat yang telah merasakan sendiri pelayanan yang diberikan oleh Kantor Camat Idi Tunong.

\section{Budaya Kerja yang Dipengaruhi oleh Perilaku Pemimpin}

Keberhasilan suatu organisasi tentu tidak lepas dari cara pemimpin dalam memberikan arahan dan motivasi kepada bawahannya. Tidak bisa dipungkiri bahwa kinerja yang diberikan oleh pegawai dapat memberikan dampak terhadap keberhasilan organisasi tersebut. Kepemimpinan tentu menjadi salah satu faktor yang dapat mendukung keberhasilan organisasi, seorang pemimpin harus mampu menciptakan dan menunjukkan perilaku serta suasana kerja yang mendukung terciptanya sikap dan kinerja pegawai yang baik. Tindakan dari pemimpin akan menjadi sebuat cerminan dan teladan bagi seluruh pegawainya dan juga tindakan pemimpin akan dinilai langsung oleh pegawainya karena mereka selalu berinterkasi dalam bekerja.

Seorang pemimpin yang mencerminkan tindakan yang baik tentu pegawai akan merasa segan dan menghormatinya tetapi apabila tindakan yang dilakukan seorang pemimpin lebih kearah negatif maka hal tersebut juga akan mengurangi rasa hormat pegawai kepada pemimpinnya. Budaya kental daerah yang juga masih dipertahankan oleh para pegawai Kantor Camat Idi Tunong membuat Camat sebagai pimpinan di Kantor Camat Idi Tunong harus menjadi lebih berhati-hati untuk tidak dapat menyinggung atau merendahkannya. Oleh karena kepemimpinan Camat akan sangat mempengaruhi budaya organisasi dan juga budaya kerja pegawainya. Mengenai kepemimpinan yang dapat mempengaruhi budaya kerja pegawai di Kantor Camat Idi Tunong, Bapak Camat Idi Tunong, Bapak Bai Haqi, S.Ag memberikan penjelasan mengenai kepemimpinan dalam mempengaruhi budaya kerja pegawai Camat Idi Tunong.

Kepemimpinannya di Kantor Camat Idi Tunong telah semaksimal mungkin dijalankan dengan baik agar memberikan cerminan kepada pegawainya, tetapi hanya karena Camat bukan putra daerah Kecamatan Idi Tunong membuat rasa hormat dari begawai sedikit berkurang.

Perilaku seorang pemimpin sangat mempengaruhi keberhasilan sebuah organisasi sebab tindakan nyata dari seorang pemimpin yang akan menjadi cerminan bagi para pegawainya. Pemimpin harus dapat menjadikan ucapannya selaras dengan tindakannya karena akan menjadi panutan pegawai. Mengenai perilaku pemimpin Camat Idi Tunong telah memperlihatkan contoh yang baik kepada pegawai, seperti yang telah dijelaskan oleh salah satu pegawai kantor Camat Idi Tunong menyatakan bahwa Camat Idi Tunong selalu hadir tepat waktu dari pada pegawai lainnya. Sehingga perilaku tersebut akan memberikan sebuah motivasi kepada pegawai untuk dapat hadir tepat waktu dalam bekerja. 
Camat Idi Tunong selaku seorang pemimpin telah memberikan contoh teladan yang baik bagi para pegawai dalam hal disiplin, para informan menjelaskan bahwa Camat sangat disiplin dalam waktu. Walaupun demikian tetapi perilaku yang di cerminkan oleh Camat tidak sepenuhnya memberikan sebuah perubahan yang besar terhadap para pegawainya. Seperti yang telah dijelaskan pada sub bab pembahasan mengenai disiplin pegawai Kantor Camat Idi Tunong yang masih sangat kurang maksimal dalam hak disiplin terutama ketepatan dalam masuk kerja. Perilaku Camat yang disiplin ternyata tidak dapat memberikan pengaruh terhadap disiplin pegawai seperti yang telah dijelaskan oleh Darodjat. Darodjat mengatakan bawha pemimpin harus dapat memberikan pengaruh terhadap perilaku bawahannya tetapi kenyataan di Kantor camat tidak seperti itu.

Sesuai dengan apa yang telah dijelaskan oleh para informan dan Darodjat (2015: mengenai perilaku pemimpin yang menunjukkan, mencerminkan dan memberikan pengaruh kepada pegawai ternyata tidak memberikan pengaruh terhadapat pegawai. Oleh karena itu disini Peneliti memberikan kesimpulan bahwa perilaku pemimpin atau Camat Idi Tunong tidak dapat memberikan pengaruh terhadap budaya kerja pegawai di Kantor Camat Idi Tunong terlihat dari masih banyak pegawai yang kurang makasimal dalam disiplin.

\section{Budaya Kerja yang Dipengaruhi oleh Seleksi Pegawai Seleksi Pegawai}

Faktor selanjutnya yang dapat memberikan pengaruh terhadap budaya kerja pegawai Kantor Camat Idi Tunong adalah seleksi pegawai. Pentingnya seleksi pegawai adalah untuk memperoleh pegawai yang memiliki kualitas yang terbaik. Proses seleksi dilakukan untuk dapat memilih pegawaipegawai yang paling memenuhi kriteria untuk mengisi posisi yang tersedia dengan harapan mereka dapat memberikan kotribusinya untuk dapat mencapai tujuan instansi mereka bekerja. Selain untuk dapat memperoleh pegawai yang berkualitas, seleksi pegawai juga akan memberikan pengaruh terhadap budaya kerja. Seperti perekrutan pegawai pada jabatan tertentu harus sesuai dengan latar belakang pendidikan yang dimilikinya agar ketika pegawai tersebut bekerja lebih produktif karena memang dia ditempatkan sesuai dengan kemampuannya.

Menurut Drodjat (2015) bahwa salah satu faktor yang dapat memberikan sebuah pengaruh terhadap budaya kerja organisasi adalah seleksi para pekerja. Dengan menempatkan pegawai yang tepat dalam kedudukan yang tepat, akan menumbuhkembangkan rasa memiliki dari para pegawai. Selain itu dengan diadakannya seleksi pegawai dengan harpan untuk mendapatkan sumber daya manusia yang berkualitas untuk dapat memperlancar kinerja organisasi. Tetapi pada kenyataannya sesuai hasil wawancara yang Peneliti lakukan ditemukan fakta bahwa di Kantor Camat Idi Tunong masih terdapat pegawai yang ditempatkan tidak sesuai dengan latar belakang pendidikan yang dimiliki meski proses perekrutan telah dilaksanakan sesuai dengan prosedur. Hal tersebut sudah tidak sesuai dengan yang dinyatakan oleh Darodjat (2015) bahwa seleksi pegawai dapat memberikan pengaruh terhadap budaya kerja selain perekrutan pegawai dilakukan untuk mengisi kekosongan jabatan tetapi juga pegawai harus ditempatkan sesuai dengan kemampuan yang dimiliki agar pegawai tersebut dapat mencintai pekerjaannya kemudian memberikan kemampuan terbaiknya dalam bekerja. Jika pegawai ditempatkan dibidang yang bukan sesuai dengan latar belakangnya maka dapat dipastikan hak tersebut menjadi beban yang pada akhirnya kemampuan bekerja tidak maksimal.

Berdasarkan hasil dari wawancara bahwa hampir semua informan menyatakan bahwa seleksi pegawai memang telah sesuai dengan aturan yang berlaku hanya saja pada penempatan jabatan yang harus sesuai dengan kemampuannya atau latar belakang pendidikan pegawai tidak terlaksana serta keterlambatan pegawai dalam penyelesaian tugas dan pelayanan yang diterima oleh masyarakat menjadi kurang maksimal, sehingga dapat dikatakan bahwa seleksi pegawai tidak memberikan pengaruh terhadap peningkatan budaya kerja di Kantor Camat Idi Tunong. 


\section{Budaya Kerja yang Dipengaruhi oleh Budaya Organisasi}

Budaya organisasi adalah nilai-nilai, norma dan perilaku yang dilaksanakan oleh para pegawai dalam suatu instansi yang lama kelamaan menjadi budaya yang mencerminkan tingkah laku para pegawainya. Perkembangan budaya organisasi akan memberikan pengaruh yang sangat besar kepada budaya kerja pegawainya karena budaya kerja itu sendiri juga merupakan nilainilai, sikap, perilaku, hasil kerja para pengawai dalam instansi. Mengenai budaya organisasi yang mempengruhi budaya kerja pegawai Kantor Camat Idi Tunong.

Budaya organisasi adalah nilai, norma, pola pikir dan perilaku yang dilaksanakan pegawai pada setiap aktifitasnya sehari-hari dalam bekerja. Kebiasaan yang dilakuakn oleh para pegawai secara terus menerus dan lama kelamaan menjadikan sebuah budaya kerja yang tertanam secara kuat. Budaya organisasi dapat memberikan pengaruh terhadap budaya kerja organisasi. Perilaku pegawai akan memberikan hasil yang sangat signifikan terhadap kualiatas pekerjaan dan pelayan yang diberikan terhadap masyarakat. Melihat kembali hasil wawancara dari para informan bahwa budaya di Kantor Camat Idi Tunong masih sangat kental dengan budaya setempat sehingga memberikan pengaruh terhadap kinerja pegawai seperti dalam satu bulan ada satu hari dimana masyarakat setempat melakukan acara adat atau kenduri maka pada hari acara tersebut maka banyaknya pegawai yang tidak masuk kerja karena lebih memilih menghadiri acara tersebut daripada masuk kerja. Hal lainnya mengenai pengaruh budaya organisasi Kantor Camat Idi Tunong yang telah lama ada adalah seperti penjelasan dari masyarakat yang mengeluhkan bahwa budaya yang masih banyak harus di perbaiki adalah budaya disiplin.

Kurangnya disiplin pegawai merupakan budaya Kantor Camat Idi Tunong yang telah lama dan masih belum bisa seutuhnya si tuntaskan. Penjelasan dari para informan tersebut menyebutkan bahwa budaya organisasi yang ada di Kantor Camat Idi Tunong memberikan pengaruh kepada budaya kerja pengawai Kantor Camat Idi Tunong tetapi pengaruh yang disebutkan adalah pengaruh yang negatif berupa kurang maksimalnya pelayanan yang diberikan oleh
Pegawai kantor Camat kepada masyarakat dan juga kurang disiplinnya pegawai dalam hal kehadiran kerja.

\section{Budaya Kerja yang Dipengaruhi oleh Budaya Luar}

Budaya luar adalah budaya yang bukan dari dalam organisasi itu sendiri, budaya luar bisa jadi budaya orang lain seperti budaya daerah lain, budaya dari luar organisasi tersebut atau bahkan budaya dari luar negeri yang dapat memberikan pengaruh positif ataupun negatif terhadap budaya yang ada didalam organisasi. Budaya yang ada di Kantor Camat idi Tunong dapat dipengaruhi oleh budaya luar yang mengelilinginya. Hal tersebut bisa terjadi dari interaksi para pegawai Kantor Camat Idi Tunong dengan pegawai Kantor Camat lainnya, atau bisa juga kebiasaankebiasaan pegawai di dalam keluarganya terbawa ke lingkungan kerjanya di Kantor Camat Idi Tunong. Mengenai budaya luar yang menjadi faktor pengaruh dalam budaya kerja pegawai Kantor Camat Idi Tunong.

Budaya luar menjadi salah satu yang dapat memberikan pengaruh terhadap budaya kerja Kantor Camat Idi Tunong. Seperti yang telah dijelaskan oleh Darodjat (2015) bahwa budaya luar dapat memberikan pengaruh terhadap organisasi. Baik itu suasana politik, ekonomi, sosial, kebudayaan, teknologi dan lain-lain. Dari hasil wawancara memang budaya luar tidak memberikan pengaruh terhadap budaya kerja pegawai di Kantor Camat Idi Tunong terutama dalam hal kebudayaan. Budaya setempat lebih kental terasa di lingkungan para pegawai. Tetapi di luar budaya Peneliti menemukan bahwa salah satu yang memberikan pengaruh terhadap budaya kerja pegawai yaitu politik. Peneliti mengatakan hal tersebut karena selama ini Peneliti melihat bahwa pegawai yang sering terlambat masuk kerja akan mendapatkan hukuman dari Camat, tetapi ada pegawai ketika akan diberikan hukuman akan mengadu kepada kerabat yang memiliki jabatan dan kekuasan agar tidak jadi dihukum.

Seperti yang dijelaskan oleh Darodjat bahwa budaya luar juga dapat memberikan pengaruh terhadap budaya kerja pegawai. Memang budaya luar seperti kebudayaan tidak memberikan pengaruh kepada pegawai karena masih kental dengan adat sendiri, tetapi seperti politik telah memberikan dampak 
terhadap budaya kerja Kantor Camat Idi Tunong. Walaupun hasil wawancara dengan para informan mengatakan budaya luar tidak memberikan pengaruh kepada budaya kerja pegawai Kantor Camat karena memang Peneliti hanya bertanya mengenai budaya saja, tetapi disini Peneliti tetap memberikan kesimpulan bahwa budaya luar memberikan pengaruh terhadap budaya kerja pegawai di Kantor Camat Idi Tunong terutama bidang politik.

\section{Budaya Kerja yang Dipengaruhi oleh Kejelasan Misi Organisasi}

Visi dan misi merupakan tujuan dari instansi tersebut berdiri kemana arah tujuan, target yang harus dicapai dan bagaimana instansi tersebut mencapainya. Visi dan misi dapat dikatakann sebagai motor penggerak para pegawai yang bekerja didalamnya serta menjadi petunjuk arah jalannya instansi. Setiap pegawai yang ada di Kantor Camat Idi Tunong wajib mengetahui apa yang menjadi visi dan misi tempat mereka bekerja, kerana visi dan misi merupakan arah dan tujaun Kantor Camat Idi Tunong dibentuk. Kejelasan visi dan misi juga akan memberikan pemahaman kepada pegawai secara jelas pekerjaan yang harus mereka lakukan dan juga akan memberikan pengaruh terhadap budaya kerja pegawai.

\section{Budaya Kerja yang Dipengaruhi oleh Kepastian Visi dan Misi}

Budaya kerja pegawai tentu dapat dipengaruhi oleh kepastian visi dan misi, tidak jauh berbeda dengan kejelasan visi dan misi diatas, jika visi dan misi telah jelas maka pelaksaan visi dan misi tentu akan sangat jelas, visi dan misi merupakan tujuan instasni dan cara untuk mencapai tujuan tersebut maka disini seorang pemimpin atau Camat Idi Tunong harus dapat menggerakkan seluruh pegawai untuk bersama-sama melaksanakan visi dan misi itu. Kepastivian visi dan misi dalam mempengaruhi budaya kerja pegawai Kantor Camat Idi Tunong.

Jika tujuan dari sebuah organisasi telah ditetapkan maka yang harus dilakukan oleh seorang pemimpin dan juga para pegawainya adalah memastikan misi tersebut berjalan. Misi organisasi telah jelas sehingga setiap anggota yang ada didalamnya telah mengetahui secara jelas dan terperinci mengenai apa yang harus dilakukan untuk dapat mencapai tujuan organisasi. Pegawai Kantor Camat Idi Tunong telah mengetahui dengan jelas mengenai misi yang harus mereka laksanakan tetapi pada hakikatnya hal tersebut belum dilaksanakan dengan maksimal. Peneliti menyatakan hal tersebut terlihat dari hasil wawancara dengan para informan seperti pegawai yang menyatakan bahwa mereka telah menjalankan tugas yang diembankan kepadanya sesuai dengan misi Kantor Camat Idi Tunog, tetapi disisi lain yang dapat memberikan penilaian adalah masyarakat yang merasakan langsung pelayanan yang diberikan. Informasi yang didapat dari masyarakat bahwa pelayanan yang diberikan masih kurang maksimal seperti masih seringnya masyarakat terlebih dahulu sampai di Kantor Camat Idi Tunong dari pada pegawai yang bertugas.

Dari penjelasan diatas dapat disimpulkan bahwa kepastian misi organisasi seperti yang dijelaskan oleh Darodjat (2015) ternyata masih belum bisa memberikan pengaruh terhadap budaya kerja pegawai di Kantor Camat Idi Tunong, hal tersebut didukung dari penjelasan masyarakat yang masih kurang maksimal dalam menerima pelayanan yang didapatkan dari Kantor Camat Idi Tinong.

\section{Budaya Kerja yang Dipengaruhi oleh Keteladanan Pemimpin}

Seorang pemimpin harus memberikan contoh yang terbaik kepada para pegawai yang menjadi bawahannya baik dalam berbagai hak untuk dapat mencapai tujuan bersama. Keteladan yang harus di cerminkan oleh seorang pemimpin seperti menjalin hubungan baik dengan bawahannya, memberikan mereka kepercayaan, serta memberikan motivasi dan semangat kerja yang tinggi. Keteladan yang pemimpin contohkan terutama kinerja tentu akan memberikan pengaruh terhadap kinerja pegawainya juga.

Darodajat (2015) menyatakan bahwa salah satu faktor yang dapat memberikan pengaruh terhadap budaya kerja adalah keteladanan pemimpin. Keteladanan pemimpin merupakan hal yang sangat penting dalam mencapai tujuan dari organisasi. Pemimpin harus memberikan atau mencontohkan teladan yang baik agar para bawahannya dapat menirunya. Seperti yang 
dikatakan Darodjat bahwa keteladan yang diberikan oleh pemimpin seharusnya memberikan pegaruh terhadap budaya kerja pegawainya, tetapi di Kantor Camat Idi Tunong sesuai dengan hasi wawancara yang dilakukan Peneliti bahwa Camat Idi Tunong telah memberikan contoh teladan yang baik terutama dalam hal disiplin walaupun demikian pegawai Kantor Camat Idi Tunong masih belum dapat sepenuhnya mencontohnya. Sehingga keteladaaan pemimpin masih belum dapat memberikan pengaruh terhadap budaya kerja pegawai, alasan lainnya juga mendukung bahwa keteladanan tidak berpengaruh karena masyarakat masih belum merasakan peningkatan pelayanan dari pegawai Kantor Camat Idi Tunong meskipun Camat telah memberikan contoh teladan.

\section{Budaya Kerja yang Dipengaruhi oleh Proses Pembelajaran}

Proses pembelajaran adalah kegiatan yang dilakuan agar pegawai dapat meningkatkan kemampuannya baik dari segi pengetahuan, keahlian dan juga untuk dapat memberikan peningkatan pelayana kepada masyarakat. Pembelajaran pegawai tetap terus berlanjut dan dipupuk untuk dapat menghasilkan budaya kerja yang sesuai dengan kebutuhan masyarakat di Kecamatan Idi Tunong. Mengenai proses pembelajaran yang akan memberikan pengaruh terhadap budaya kerja pegawai Kantor Camat Idi Tunong

Untuk menghasilkan budaya kerja yang sesuai maka para pegawai membutuhkan pengembangan keahlian dan pengetahuan melalui proses pembelajaran. Dengan adanya proses pembelajaran pegawai diharapkan dapat memberikan pengaruh kepada kualiatas kerja. Pentingnya proses pembelajaran kepada pegawai adalah untuk meningkatkan kepribadian dan semangat pengabdian pegawai kepada organisasi dan masyarakat, meningkatkan keterampilan, melatih mekanisme kerja dan kepekaan dalam melaksanakan tugas yang apabila dilaksanakan secara terus menerus dan berkelanjutan akan menjadikan hal tesebut sebuah budaya kerja yang positif. Proses pembelajaran yang dilaksanakan pada Kantor Camat Idi Tunong telah memberikan pengaruh terhadap budaya kerja pegawai. Hal tersebut sesuai dengan yang dijelaskan oleh Darodjat dan juga dengan hasil wawancara dengan para pegawai yang mengatakan bahwa setelah pegawai Kantor Camat mengikuti pelatihan dan pendidikan telah meningkatkan kualitas pelayanan yang diberikan kepada masyarakat.

\section{Budaya Kerja yang Dipengaruhi oleh Motivasi}

Motivasi juga menajdi faktor yang memberikan pengaruh terhadap budaya kerja pegawai Kantor Camat Idi Tunong. Motivasimotivasi yang diberikan akan membuat pegawai memahami keberadaan mereka sebagai seorang pegawai yang memberikan pelayanan kepada masyarakat, pegawai bekerja di Kantor Camat memang tugas utamanya untuk dapat memberikan pelayanan terbaik kepada masyarakat, sehingga dengan motivasi tersebebut mereka lebih meningkatkan budaya kerjanya. Selain itu dengan adanya motivasi maka pegawai lebih terdorong melaksakan pekerjaan dengan sungguh-sungguh.

Motivasi menjadi salah satu faktor yang memberikan pengaruh terhadap budaya kerja sebab apabila pegawai telah diberikan motivasi atau dorongan maka mereka akan lebih bersemangat dalam bekerja. Walaupun kita mengetahui bahwa setiap pegawai memiliki motivasi berbeda dalam bekerja misalnya seperti motivasi untuk berprestasi, motivasi berafiliasi atau motivasi akan kekuasaan tetapi diharapkan hal tersebut memberikan pegawai untuk terus memberikan kinerja tebaiknya dan apabila dilaksanakan dalam waktu yang lama dapat dipastikan menjadi seuah budaya kerja positif. Mengenai motivasi sebagai salah satu faktor yang memberikan pengaruh terhadap budaya kerja di Kantor Camat Idi Tunong juga telah dijelaskan para informan melalui wawancara yang telah peneliti lakukan. Wawancara tersebut disimpukan bahwa pemberian motivasi kepada pegawai dapat memberikan pengaruh terhadap budaya kerja pegawai Kantor Camat Idi Tunong selain telah sesuai dengan penjelasan Darodjat dan penjelasan dari para innforman meskipun tidak semua pelayanan yang meraka berikan dapat membuat masyarakat menjadi puas. 


\section{SIMPULAN}

Budaya kerja di Kantor Camat Idi Tunong yang terdir dari keterbukaan informasi; saling menghargai; kerjasama antar pegawai sudah berjalan dengan baik walaupun demikian dalam hal kedisiplinan pegawai masih kurang maksimal. Faktor-faktor yang mempengaruhi budaya kerja di Kantor Camat Idi Tunong seperti perilaku budaya organisasi; budaya luar; proses pembelajaran dan motivasi telah memberikan pengaruh terhadap budaya kerja Kantor Camat Idi Tunong, sedangkan untuk perilaku pemimpin; seleksi pegawai; kejelasan visi dan misi; kepastian visi dan misi; keteladanan pemimpin masih belum memberikan pengaruh budaya kerja yang ada di Kantor Camat Idi Tunong.

\section{DAFTAR PUSTAKA}

Darodjat, T.A. (2015). Pentingnya Budaya Kerja Tinggi dan Kuat Absolute. Bandung: PT. Refika Aditama.

Frinaldi, A. (2011). "Analisis Budaya Kerja Disiplin Pegawai Negeri Sipil: Studi Pada Beberapa Pemerintah Daerah Di Sumatera Barat". Jurnal Demokrasi, 10 (2) : 125-126.

Hasibuan, SP. (2000). Manajemen Sumber Daya Manusia. Jakarta: PT. Bumi Aksara.

Hasibuan, SP. (2005). Manajemen Sumber Daya Manusia. Jakarta: PT. Bumi Aksara.

Hasibuan, SP. (2007). Manajemen Sumber Daya Manusia. Jakarta: PT. Bumi Aksara.

Hatalea, A., Rusmiwari, S. dan Aminullah, A. (2014). "Budaya Kerja Pegawai Negeri Sipil". Jurnal Ilmu Sosial dan Ilmu Politik, 3 (2): 6-10.

Idrus, M. (2009). Metode Penelitian Ilmu Sosial: Pendekatan Kualitatif dan Kuantitatif. Yogyakarta: Erlangga.

Lufni, A. (2013). "Studi Tentang Budaya Kerja Aparatur Kecamatan Samboja, Kabupaten Kutai Kartanegara". Jurnal Paradigma, 2 (2): 214.

Martono, N. (2016). Metode Penelitian Sosial: Konsep-Konsep Kunci. Jakarta: PT. Rajagrafindo Persada.

McSahne, dkk. (2010). Organization Behavior. New York: McGraw-Hill.

Moeloeng, L.J. (2003). Metodologi Penelitian Kualitatif. Bandung: PT. Remaja.

Moenir. (1983). Pendekatan Manusia dan Organisasi Terhadap Pembinaan Kepegawaian. Jakarta: Gunung Agung.

Muamar. (2017). "Pengaruh Kepuasan Kerja, Disiplin Kerja, Dan Budaya Kerja Terhadap Kinerja Pegawai Pada Dinas Tenaga Kerja Dan Trasnmigrasi Provinsi Sulawesi Tengah". Jurnal Katalogis, 5 (7): 10.
Mujiburrahman, (2011), Hubungan Antara Pendidikan, Motivasi Dan Budaya Kerja Dengan Kinerja Pegawai (Studi Pada Inspektorat Kabupaten Aceh Timur), Jurnal Administrasi Publik : Public Administration Journal : Public Admnistration Journal, 1 (2):160-169

Ndraha, T. (2005). Teori Budaya Organisasi. Jakarta: PT. Rineka Cipta.

Nurmayanti, I. (2015). Peran Pendidikan Dan Pelatihan (DIKLAT) Dalam Meningkatkan Kinerja Pegawai. Widyais Balai Diklat Kehutanan Bogor.

Robbins, SP. (2002). Prinsip-prinsip Perilaku Organisasi. Jakarta: Erlangga.

Sastrohadiwirjo dan Siswanto. (2002). Manajemen Tenaga Kerja Indonesia: Pendekatan Administratif dan Operasional. Jakarta: Bumi Aksara.

Saydam, G. (2000). Manajemen Sumber Daya Manusia. Jakarta: Binarupa.

Siagian, S.P. (2009). Manajemen Sumber Daya Manusia. Jakarta: Bumi Aksara.

Silalahi, U. (2009). Metode Penelitian Sosial. Bandung: PT. Refika Aditama.

Sofyan, A, dkk. (2015). "Pengaruh Keteladanan Kepemimpinan Dan Penerapan Peraturan Terhadap Disiplin Dan Dampaknya Pada Kenerja Pegawai Dinas Kesehatan Kabupaten Aceh Jaya". Jurnal Manajemen Pascasarjana Universitas Syiah Kuala, 4 (3) : 101-111.

Sudarman, E. (2018). "Pengaruh Budaya Kerja Dan Komitmen Organisasi Terhadap Kinerja Pelayanan Publik Di Dinas Pariwisata Dan Kebudayaan Kabupaten Karawang". Jurnal Study \& Management Reseach, 15 (1) : 71-84.

Suyadi, P. (2000). Kebijakan Kinerja Pegawai. Kiat Membangun Organisasi Kompetitif Menjelang Perdagangan Bebas Dunia. Yogyakarta: BPFE.

Suyanto, B. dan Situnah. (2005). Metode Penelitian Sosial: Berbagai Alternatif Pendekatan. Jakarta: Kencana Prenada Media Group.

Tika, M.P. (2008). Budaya Organisasi dan Peningkatan Kinerja Perusahaan. Jakarta: Bumi Aksara.

Triguno. (2004). Budaya Kerja: Menciptakan Lingkungan Yang Kondisif Untuk Meningkatkan Produktivitas Kerja. Jakarta: PT. Bumi Aksara.

Wibowo. (2013). Perilaku Dalam Organisasi. Depok: PT. Rajagrafindo Persada.

Widagho, D. (2004). Ilmu Budaya Dasar. Jakarta: PT. Bumi Aksara.

Yullyanti, E. (2009). "Analisis Proses Rekrutmen Dan Seleksi Pada Kinerja Pegawai" Jurnal Administrasi dan Organisasi, 16 (3) : 131-139 
Cut Sri Maulina, Humaizi \& Nurman Achmad. Budaya Kerja Aparatur Sipil Negara pada Kantor Camat Idi

Zulkifli. (2014). “Hubungan Budaya Kerja Dengan Komitmen Pagawai Negeri Sipil Di Lingkungan Rumah Sakit Jiwa Daerah Atma Husada Mahakam". E-Jourrnal Administrative Reform, 2 (2) : 1316-1327.

\section{Peraturan Perundang-Undangan}

Undang-Undang No. 5 Tahun 2014 tentang Aparatur Sipil Negara.

Peraturan Pemerintah No. 53 Tahun 2010 tentang Peraturan Disiplin Pegawai Negeri Sipil.

Peraturan Menteri Pendayagunaan Aparatur Negara Dan Reformasi Birokrasi Republik
Indonesia No. 39 Tahun 2012 tentang Pedoman Pengembangan Budaya Kerja.

\section{Sumber Lainnya :}

Tribunnews.com. 2018. Dari 1.759 Orang Kena Hukuman Disiplin, 96 PNS Diberhentikan Tidak Hormat Pada Tahun 2017, http://www.tribunnews.com/nasional/201 8/02/08/dari-1759-orang-kena-hukumandisiplin-96-pns-diberhentikan-tidak-hormatpada-2017. Diakses Pada Tanggal 27 Oktober 2018 Pukul 13:45 WIB. 